\title{
Analiza statističkih podataka IOM-a vezanih za migracije na južnim granicama Europske unije 2015. $-2018 .^{1}$
}

\author{
Antonio Vulas \\ Policijski savjetnik \\ Voditelj Službe za nezakonite migracije Policijske uprave splitsko-dalmatinske \\ $\checkmark$ E-mail: avulas.st@gmail.com
}

\begin{abstract}
Sažetak
Članak se bavi problemom interpretacije statističkih podataka vezanih za kretanje migracija na južnim granicama Europske unije u razdoblju od 2015. do 2018. godine. Koristeći statističke podatke, koje je izradila specijalizirana institucija UN-a, nastoji se upozoriti na problem priljeva migranata nakon okončanja "velike migrantske krize 2015./2016." te na probleme interpretacije statističkih podataka za to razdoblje. Naglašavajući važnost statistike za prethodna razdoblja u pogledu određivanja aktivnosti u budućnosti, nastoji se naglasiti važnost analiziranja statističkih promjena i čimbenika koji su na njih utjecali. Naglasak je stavljen na autorovo promišljanje o čimbenicima koji su utjecali na statističke promjene te na određivanje prirode njihova utjecaja na statistička kretanja. Pritom se upozorava da bi se u svakoj analizi statističkih promjena naglasak morao staviti na definiranje čimbenika koji su utjecali na statističke promjene, na određivanje prirode tih čimbenika, na njihovu trajnost te na mogućnost ponavljanja takvih utjecaja u budućnosti.
\end{abstract}

Ključne riječi: migracije, južne granice Europske unije, statistički pokazatelji, Međunarodna organizacija za migracije

\section{Uvod}

Kraj svake kalendarske godine donosi slaganje godišnjih statistika kojima se protekla godina uspoređuje s onom prije nje i na osnovi koje se rade planovi za narednu godinu. $U$ tome nije iznimka ni 2018. godina. U nizu podataka koji se statistički obrađuju, podatci vezani za ulazak migranata na područje Europske unije čine jednu od politički najosjetljivijih tema danas. Sjetimo se samo uloge koju je u kampanji za izlaz Ujedinjenog Kraljevstva imala tema o broju migranata koji u sklopu unutarnjih migracija uđu iz ostalih država članica na Otok (Dennison i Geddes, 2018), a radilo se samo o unutrašnjoj migraciji.

Europska unija u zadnjih nekoliko godina suočava se s problemom nekontroliranih migracija preko njezinih južnih granica. Prije svega radi se o ulasku migranata na područje EU-a takozvanim sredozemnim rutama; zapadnom (Španjolska), srednjom (Italija i u neznatnoj mjeri Malta) te istočnom (Grčka). Ulasci migranata kopnenim putem iz Turske u Bugarsku također su dio problema ovakvih migracijskih kretanja preko južnih granica EU-a.

1 Mišljenja i stavovi izneseni u radu ne predstavljaju nužno službeni stav MUP-a RH. 
Ako prihvatimo tvrdnju „pojedinačne i migracije manjih skupina povijesna su konstanta i ljudska potreba" (Mikac i Dragović, 2017) kao činjenicu koju je teško osporiti, gubitak kontrole nad migracijskim kretanjima preko granica predstavlja problem za svaku državu ili, pak, uniju država. Pod gubitkom kontrole nad migracijskim kretanjima prije svega bismo mogli smatrati nemogućnost države da učinkovito spriječi nezakonite prelaske državne granice, dakle prijelaze državne granice izvan određenih graničnih prijelaza i bez ispunjavanja zakonskih uvjeta za prelazak državne granice. Vurnek, Bengaz i Perkov (2018) navode da nezakonite migracije mogu biti organizirane, neorganizirane i poluorganizirane, a kao najopasnije navode one koje su nezakonite i organizirane.

Tijekom druge polovice 2015. i prvog tromjesečja 2016. godine Europska unija suočila se s priljevom migranata kakav Europa ne pamti od završetka Drugoga svjetskog rata. Arapsko proljeće, koje je počelo političkim nemirima u Tunisu 2010. godine, a koje se kasnije prenijelo na Libiju i na Egipat, da bi naposljetku 2011. godine stiglo i u Siriju, uzrokovalo je pokretanje vala migranata prema Europskoj uniji. Tom valu, uglavnom sirijskih izbjeglica, pridružili su se svi oni koji su nastojali pobjeći iz političkih i/ili ekonomskih neodrživih prilika u zemljama središnje Azije, Bliskog istoka i Afrike (Akrap i Kalinić, 2015).

Unatoč tomu što se možemo složiti da „Unija u pravilu nije uzrokovala sukobe na prostoru Bliskog istoka" (Mikac i Dragović, 2017), politike pojedinih država članica Unije imale su značajnu ulogu u razvoju političkih potresa na tom prostoru. Osobito ako ih promatramo u povijesnom kontekstu.

Dijelom upravo te povijesne veze s nekadašnjim kolonizatorskim "gospodarima" postoje razlozi privlačenja migranata prema Europi. Ipak, može se zaključiti da je jedan od glavnih razloga geografska blizina Europe te status Europe kao područja na kojemu se poštuju temeljna prava, a ekonomska situacija je takva da migrantima pruža mogućnost dostojanstvena života.

Gubitak učinkovite kontrole nad migracijskim kretanjima preko državne granice, barem u razdoblju druge polovice 2015. i prvog tromjesečja 2016. godine ne znači da države članice i sama Unija, nisu pokušavale registrirati i zabilježiti podatke o osobama koje su granicu prošle nezakonito. Taj posao postao je mnogo lakši nakon što je u travnju i svibnju 2016. godine došlo do stabiliziranja stanja na južnim granicama.

Upravo ti statistički podatci fokus su ovog rada. Statističko praćenje broja novopridošlih migranata na područje Europske unije nakon „migrantske krize 2015./2016.” dobilo je na važnosti. Ti podatci, i oni službeni i oni neslužbeni, postaju predmetom interesa i javnosti i političara. Možemo slobodno reći da se oko ovih statističkih podataka počinje vrtjeti širok spektar političkih snaga u Uniji, a sve radi dokazivanja ispravnosti njihovih stavova o useljavanju na područje EU-a. Neki se svim silama trude brojevima dokazati da velik broj migranata, koji svake godine ulaze u EU, ugrožava njezinu opstojnost. S druge strane, imamo one koji tim istim brojevima nastoje dokazati da se ne radi o nekom fenomenu koji može ugroziti Uniju, već dapače da su brojevi u okvirima koji odgovaraju Uniji s obzirom na njezinu trenutnu ekonomsku i populacijsku sliku.

No, bez obzira na prirodu i posljedice tog fenomena podatci iz tog razdoblja 2015./2016. godine stvorili su jednu veliku statističku "anomaliju" koja će kasnije pružiti mogućnost različitih tumačenja događanja nakon okončanja "velike migrantske krize". Uz to, ako znamo da još nitko sa sigurnošću 
Antonio Vulas: Analiza statističkih podataka IOM-a vezanih za migracije na južnim...

ne može reći koliko je migranata u tom valu ušlo u Uniju, onda uviđamo još veću kompleksnost statističkih uspoređivanja.

Vrlo često su te, gore spomenute, različite interpretacije rezultat različitih početnih stavova interpretatora i ciljeva koje isti žele postići interpretiranjem tih podataka. Pritom se u statistiku nekritički "umeću" podatci iz 2015. i 2016. godine koji uvelike utječu na cjelokupnu sliku.

Ipak, primarni zadatak ovog rada nije pokušaj davanja odgovora o uzrocima, prirodi i rezultatima pojedinih čimbenika koji su utjecali na statističke podatke, iako se u njemu ne može pobjeći od isticanja činjenice o utjecaju pojedinih čimbenika na statistiku da bi je bolje protumačili.

\section{Cilj i svrha analize}

Kao što je rečeno u uvodu, svrha ovog rada nije upozoravanje na ispravnost bilo kojeg od političkih ili društvenih stavova vezanih za migracije, temeljenih na statističkim podatcima o migracijama. Analiza statističkih podataka, koje iznosimo u tekstu metodom usporedbe kretanja broja migranata na trima glavnim rutama ulaska migranata u EU preko njezinih južnih granica - zapadnosredozemne (Španjolska), srednjosredozemne (Italija) i istočnosredozemne (Grčka), pokušava pokazati da migracijska kriza na takozvanoj zapadnobalkanskoj ruti ne jenjava, unatoč tomu što je danas broj ulazaka migranata daleko manji nego 2015. godine. Podatci izneseni u statistikama vrlo često skrivaju jednako onoliko koliko i otkrivaju. Kao što se ljepota skriva u oku promatrača, tako se istina o statistici skriva u znanju analitičara.

Promatrajući statističke podatke vezane za ulazak migranata u EU preko ovih ruta kretanja, njihovu međusobnu povezanost, s posebnim naglaskom na istočnosredozemnu rutu, nastoji se pokazati da EU još uvijek ne može reći da ima punu kontrolu nad svojim južnim granicama.

U ovom radu nastoji se analizirati statističke podatke o kretanju migracija u Europskoj uniji pokušavajući ih povezati s pojedinim političkim čimbenicima koji su prema mišljenju autora utjecali na stanje na terenu i samim time na statističke podatke. Pritom se također ne želi ulaziti u korijene i razlog nastanka tih čimbenika, jednako kao što se nastoji ne zauzimati stav o tim čimbenicima. Unatoč tomu što se to ponekad može činiti kao namjerno i nepotrebno kvarenje dobre slike, dužnost nam je statističke podatke pogledati "iz svih uglova". Postojanje tih čimbenika mora se konstatirati i upozoriti na moguće utjecaje koji se odražavaju na statističku sliku stanja na terenu.

Ako znamo da brojevi ne lažu, onda znamo da se ne smijemo bojati ni naših zaključaka na temelju brojeva. Tim više što od pravilno izvedenih zaključaka o ovim podatcima može ovisiti planiranje i aktivnosti u narednom razdoblju.

Čak i ako se složimo s tvrdnjom potpredsjednika Europske komisije Fransa Timmermansa, izrečenom početkom ožujka 2019., da se može smatrati da je "migrantska kriza okončana“2, postavlja se pitanje - možemo li smatrati da je Europska unija vratila kontrolu nad migracijskim kretanjima na svojim južnim granicama. Cilj je ovog rada uporabom statističkih pokazatelja upozoriti na to da Europska unija još uvijek ne kontrolira migracijska kretanja na tom dijelu svojih vanjskih granica.

$\overline{2}$ Vidi (https://www.msn.com/en-ie/news/world/eu-declares-migration-crisis-over-as-it-hits-out-at-fake-news/ar-BBUrFQt) 


\section{Metodologija analize}

Kada govorimo o statistici koja se odnosi na migracijska kretanja u Europskoj uniji, moramo znati da danas postoji cijeli niz službenih statistika o tome. Neke su produkt vladinih, odnosno Unijinih tijela i organizacija. $S$ druge strane, postoje i statistike koje su izradile mnoge nevladine organizacije (tzv. NGOs) koje su angažirane na polju priljeva migranata u Europsku uniju.

I jedni i drugi mogu se pohvaliti stručnim pristupom, no s obzirom na to da ne postoje mehanizmi kojima bi se mogla jamčiti apsolutna točnost podataka, određena odstupanja među tim statistikama neizbježna su.

U ovoj analizi korišteni su isključivo statistički podatci Međunarodne organizacije za migracije (International Organization for Migration - IOM), ${ }^{3}$ a sve tablice i dijagrame prikazane u ovom radu izradio je autor ovog rada. S obzirom na to da je ta organizacija od 2016. godine postala organizacija Ujedinjenih naroda, isključivo specijalizirana za pitanja migracija, raseljenih osoba, izbjeglica i stranih radnika, taj izvor uzet je kao izvor u koji se može maksimalno vjerovati. ${ }^{4}$ Podatci izneseni u Godišnjoj analizi rizika za 2019., koju je izdala Agencija za europsku i obalnu stražu (European Border and Coast Guard Agency, FRONTEX), službeno tijelo Europske unije zaduženo za nadzor vanjskih granica EU-a, potvrđuju pouzdanost ovog primarnog izvora (FRONTEX, 2019).

Nažalost, na spomenutoj stranici mogu se pratiti mjesečni statistički podatci vezani za priljev migranata u Europsku uniju unatrag samo do 2016. godine, dok se podatci za 2015. godinu mogu naći samo u zbirnom godišnjem izvješću organizacije (IOM, 2016).

Nadalje, u ovom radu iznose se podatci koji se odnose na Španjolsku, Italiju, Grčku i Bugarsku, kao zemlje prvog ulaska na područje Unije. Podatci koji se odnose na Cipar i Maltu, kao države prvog ulaska, nisu uvršteni u ove podatke. U odnosu na ukupne podatke o kojima govorimo u ovom radu, udio koji se odnosi na ove dvije otočne države neznatan je da bi mogao utjecati na zaključke ovog rada. Zbog toga su ti podatci i isključeni iz ovog pregleda.

\section{Rezultati i rasprava}

U dolje iznesenim tablicama donosimo statističke podatke koji se odnose na broj novopridošlih migranata za razdoblje od 2015. do 2018. godine. Kao što je naglašeno gore u tekstu, radi se o statističkim podatcima objavljenim na mrežnim stranicama Međunarodne organizacije za migracije (IOM). U tablicama se iznose podatci za Španjolsku, Italiju, Bugarsku i Grčku, dok dostupni podatci za Cipar i Maltu nisu izneseni zbog neznatna udjela u ukupnim podatcima.

U svakoj tablici iznose se podatci o novopridošlim migrantima u gore spomenute zemlje po mjesecima u godini, osim u tablici koja se odnosi na 2015. godinu gdje takvi mjesečni podatci ne postoje na službenim mrežnim tablicama IOM-a. Stoga su u toj tablici prikazani samo godišnji statistički podatci za svaku državu i ukupno za sve prikazane države.

Podatci dostupni na mrežnoj stranici: $h$ ttps://migration.iom.int/europe?type=arrivals

Više o IOM-u vidi na https://www.iom.int/ 
Antonio Vulas: Analiza statističkih podataka IOM-a vezanih za migracije na južnim...

U zadnjim stupcima, u kojima su prikazani ukupni brojevi novopridošlih migranata za svaku državu, i skupno za sve prikazane države, prikazani su i brojevi migranata koji su pridošli preko morskih granica (M) i preko kopnenih granica (K). Nažalost, takva podjela za godišnje podatke također ne postoji za 2015. godinu.

Tablica 1. Broj migranata u 2015. godini

\begin{tabular}{|c|c|}
\hline Španjolska & 3845 \\
\hline Italija & 153842 \\
\hline Bugarska & 31174 \\
\hline Grčka & 857363 \\
\hline UKUPNO & 1046224 \\
\hline
\end{tabular}

U tablici 1 izneseni su zbirni podatci s brojem migranata koji su u toj godini ušli na područje četiriju država članica koje od samih početaka "migrantskog problema" predstavljaju "države prvog ulaska” u Europsku uniju. Podatci navode velik porast broja migranata na ulasku u Bugarsku i Grčku (iz Turske). Upravo su to bile brojke koje se izazvale "veliku migrantsku krizu” 2015. godine, koja se prelila i na prvo tromjesečje sljedeće godine.

Da se radi o enormnoj statističkoj promjeni, govori nam i FRONTEX-ova Godišnja analiza rizika za 2015. godinu (FRONTEX, 2015) u kojoj se navodi da je tzv. zapadnobalkanskom rutom, koja obuhvaća Grčku i Bugarsku, kao zemlje prvog ulaska, tijekom 2012. godine nezakonito ušao 6391 migrant, potom 2013. godine 19951 migrant i naposljetku 2014. godine 43357 migranata.

Već tada moglo se naslutiti da se na "zapadnobalkanskoj ruti” nešto događa. Od 43357 migranata u 2014. godini došlo je do skoka na 888537 migranata u 2015. godini koji su u Europsku uniju ušli preko Grčke ili preko Bugarske. Statistička promjena koja se ne može gledati drukčije nego kao "statistička anomalija" koja ima svoje uzroke i objašnjenja. Za ovu pojavu postoji više objašnjenja. Počevši od zaključaka da je veliki val migranata pokrenuo rat u Siriji pa do onih da se radi o uzrocima koji se ne mogu pripisati isključivo ratu u toj zemlji budući da je započeo četiri godine prije pokretanja migrantskog vala prema Europi.

Tablica 2. Broj migranata u 2016. godini

\begin{tabular}{|c|c|c|c|c|c|c|c|c|c|c|c|c|c|c|}
\hline & 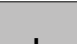 & $\mu$ & 14 & IN & $\mathrm{N}$ & $v$ & vul & ve & Ix & $\mathbf{x}$ & YI & $\mathbf{Y u}$ & M & K \\
\hline & 1. & II. & III. & IV. & v. & VI. & VII. & VIII. & IX. & X. & $\boldsymbol{X I .}$ & Ail. & UKL & No \\
\hline \multirow{2}{*}{ Španjolska } & \multirow{2}{*}{492} & \multirow{2}{*}{222} & \multirow{2}{*}{351} & \multirow{2}{*}{451} & \multirow{2}{*}{575} & \multirow{2}{*}{715} & \multirow{2}{*}{458} & \multirow{2}{*}{934} & \multirow{2}{*}{1248} & \multirow{2}{*}{1110} & \multirow{2}{*}{854} & \multirow{2}{*}{7148} & 8162 & 6396 \\
\hline & & & & & & & & & & & & & \multicolumn{2}{|c|}{14558} \\
\hline \multirow{2}{*}{ Italija } & \multirow{2}{*}{5273} & \multirow{2}{*}{3828} & \multirow{2}{*}{9676} & \multirow{2}{*}{9149} & \multirow{2}{*}{19925} & \multirow{2}{*}{22371} & \multirow{2}{*}{23552} & \multirow{2}{*}{21294} & \multirow{2}{*}{16975} & \multirow{2}{*}{27384} & \multirow{2}{*}{13962} & \multirow{2}{*}{8047} & 181436 & 0 \\
\hline & & & & & & & & & & & & & \multicolumn{2}{|c|}{181436} \\
\hline \multirow{2}{*}{ Bugarska } & \multirow{2}{*}{596} & \multirow{2}{*}{450} & \multirow{2}{*}{524} & \multirow{2}{*}{1328} & \multirow{2}{*}{1201} & \multirow{2}{*}{1436} & \multirow{2}{*}{1236} & ק? & 2615 & 2132 & 1120 & 197 & 0 & 17187 \\
\hline & & & & & & & & $40<2$ & 2045 & 2133 & (1) & 401 & & \\
\hline Gmă & 67415 & 57 & 26 & 3650 & 1721 & 1551 & 1020 & 2510 & 3052 & 2070 & 1027 & 1715 & 173614 & 0 \\
\hline Grска & 01415 & 51000 & 20971 & 3030 & 1181 & 1534 & 1920 & 3340 & 3052 & 3010 & 1932 & כדות & 173 & \\
\hline נYMAD & 73776 & 61566 & 27527 & 14578 & 23,23 & 6076 & 7166 & 700 & 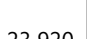 & 80 & 7877 & 07 & 363212 & 23583 \\
\hline Dotivo & & 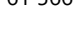 & (1) & 14510 & $254<2$ & 20010 & 21700 & ט大ot & $203<0$ & נכטד כת & (18 & הכנד וד & 386 & 95 \\
\hline
\end{tabular}

Iz podataka iznesenih u tablici 2 vidimo da je u 2016. godini došlo do značajna opadanja broja migranata, koji su u Europsku uniju ušli preko četiriju gore spomenutih država članica, u odnosu 
na 2015. godinu. To je bio velik razlog za optimizam. U travnju te godine, gotovo istovremeno, počele su davati učinak strože mjere na zaštiti državne granice u zemljama od Grčke do Austrije, okupljene u "Salzburškom forumu"5 te sporazum između EU-a i Turske, prema kojem se Turska obvezala poduzimati učinkovitije mjere u sprečavanju izlaska migranata s njezina teritorija.

Kao što vidimo, u Grčkoj, a i u Bugarskoj, dolazi do drastična smanjenja broja migranata koji ulaze iz Turske (Grčka 857363 - 173 614; Bugarska 31174 - 17 187). To je glavni razlog tako veliku padu broja migranata koji su ušli u Uniju u odnosu na broj iz 2015. godine (1 046224 - 386 795).

Ako promatramo Španjolsku i Italiju u istom razdoblju, uočit ćemo trend povećanja broja migranata, što mnogi dovode u izravnu korelaciju s velikim padom broja migranata u istočnom Sredozemlju. No, to još više osnažuje tezu o važnosti tzv. zapadnobalkanske rute na ukupan broj migranata koji uđu u Uniju.

Važno je uočiti još jednu činjenicu vezanu za broj migranata koji su tijekom 2016. godine ušli iz Turske u Grčku. U vrijeme kada se počinju osjećati utjecaji čimbenika o kojima smo govorili gore u tekstu, dolazi do nagloga pada broja novopridošlih migranata. S 26971 migrantom u ožujku 2016. godine broj u travnju pada na 3650, da bi u svibnju bio 1721. Događa se upravo suprotno od onoga što bi se moglo očekivati s obzirom na poboljšanje vremenskih prilika za prelazak morskim putem iz Turske u Grčku.

To nas dovodi do još jedne značajne činjenice. Tijekom 2016. godine broj migranata koji su u Grčku ušli iz Turske preko kopnene granice toliko je neznatan da ga statistike i ne bilježe. To će se idućih godina promijeniti.

Tablica 3. Broj migranata u 2017. godini

\begin{tabular}{|c|c|c|c|c|c|c|c|c|c|c|c|c|c|c|}
\hline & & & & & & & & & & & & & M & K \\
\hline & I. & II. & III. & IV. & V. & VI. & VII. & VIII. & IX. & $\mathrm{X}$. & XI. & XII. & & \\
\hline \multirow{2}{*}{ Španjolska } & \multirow{2}{*}{2453} & \multirow{2}{*}{1409} & \multirow{2}{*}{1342} & \multirow{2}{*}{900} & \multirow{2}{*}{945} & \multirow{2}{*}{2352} & \multirow{2}{*}{2553} & \multirow{2}{*}{2529} & \multirow{2}{*}{2194} & \multirow{2}{*}{3616} & \multirow{2}{*}{5221} & \multirow{2}{*}{3191} & 22414 & 6291 \\
\hline & & & & & & & & & & & & & \multicolumn{2}{|c|}{28705} \\
\hline \multirow{2}{*}{ Italija } & \multirow{2}{*}{4467} & \multirow{2}{*}{8972} & \multirow{2}{*}{10853} & \multirow{2}{*}{12942} & \multirow{2}{*}{22993} & \multirow{2}{*}{23524} & \multirow{2}{*}{11461} & \multirow{2}{*}{3914} & \multirow{2}{*}{6282} & \multirow{2}{*}{5988} & \multirow{2}{*}{5645} & \multirow{2}{*}{2327} & 119368 & 0 \\
\hline & & & & & & & & & & & & & \multicolumn{2}{|c|}{119368} \\
\hline \multirow{2}{*}{ Bugarska } & \multirow{2}{*}{48} & \multirow{2}{*}{50} & \multirow{2}{*}{280} & \multirow{2}{*}{347} & \multirow{2}{*}{209} & \multirow{2}{*}{158} & \multirow{2}{*}{330} & & & & & & 0 & 2562 \\
\hline & & & & & & & & 311 & 354 & 190 & 101 & 124 & & \\
\hline & & & & & & & & & & & & & 29501 & 5551 \\
\hline Grekd & 1320 & 1183 & 1702 & 1304 & $2 \angle 40$ & 2002 & 2013 & $4 \angle 40$ & $3 / 99$ & 5001 & 3801 & 2845 & & \\
\hline & & & & & & & & & & & & & 171283 & 14404 \\
\hline UKUPNO & 8488 & 11616 & 14177 & 15553 & 26393 & 28696 & 16959 & 10994 & 14629 & 14801 & 14894 & 8487 & & \\
\hline
\end{tabular}

Podatci za 2017. godinu donose brojeve koji su glavni uzrok optimizma i u političara i u dijelu javnosti. Brojevi novopridošlih migranata opadaju u svim spomenutim državama osim u Španjolskoj. U toj se državi broj migranata 2017. godine udvostručio, nakon što je u 2016. godini bio gotovo četiri puta veći nego 2015. godine.

5 Salzburški forum regionalna je organizacija srednjoeuropskih država koju čine: Austrija, Bugarska, Hrvatska, Mađarska, Češka, Poljska, Rumunjska, Slovačka i Slovenija radi jačanja suradnje na polju policijske suradnje, suzbijanja nezakonitih migracija, zaštite svjedoka, borbe protiv trgovine drogama, sigurnosti prometa i drugih oblika unutarnje sigurnosti. U ovom konkretnom slučaju države Salzburškog foruma djelovale su u suradnji sa Srbijom i Sjevernom Makedonijom, koje su bile glavne tranzitne zemlje na tzv. zapadnobalkanskoj ruti. 
Antonio Vulas: Analiza statističkih podataka IOM-a vezanih za migracije na južnim...

Godine 2017. u Italiji se počinje osjećati utjecaj „antimigrantske” politike koju su zastupali neki članovi nove talijanske Vlade. Te godine u Italiji nakon dugo vremena statistike bilježe značajan pad novopridošlih migranata. Radi se o osamdesetak tisuća migranata manje nego 2016. godine, što je velika razlika i za države ulaska kao što je Italija. No, utjecaj takve politike nove talijanske Vlade svoj pravi učinak pokazat će tek iduće 2018. godine. Te godine talijanska vlada zabranit će plovilima svih nevladinih udruga uplovljavanje u talijanske luke s migrantima koji nisu spašeni u morskim vodama koje se nalaze u zoni odgovornosti Republike Italije. Do tada su plovila raznih nevladinih udruga plovila u morske vode koje se nalaze izvan talijanske zone spašavanja (SAR zona) ${ }^{6}$, odlazeći čak i u libijske teritorijalne vode i tamo spašavale migrante s plovila koja su isplovljavala s libijske obale. Takva spašavanja obavljana su bez ikakva znanja ili koordinacije s talijanskim ICC-om nakon čega su spašene migrante dovodili u talijanske luke. U srpnju 2018. godine talijanska Vlada donosi odluku da se takvim plovilima zabrani uplovljavanje u talijanske luke, a učinci te politike jasno će se pokazati na statističkim podatcima koji su izneseni niže u tekstu.

U Grčkoj 2017. godine dolazi do deseterostruka pada broja migranata u odnosu na prethodnu godinu. Imajući u vidu ulogu Grčke, kao države ulaska čija je statistika odigrala najveću ulogu u ukupnoj statistici vezanoj za migracije u Uniji, ovo je glavni razlog za optimizam.

No, i u Grčkoj primjećujemo jednu značajnu promjenu. Za razliku od 2016. godine, kada statistike nisu bilježile ulaske migranata iz Turske u Grčku preko kopnene granice, u 2017. godini vidimo da je tim putem u Grčku ušao 5551 migrant. Bila je to promjena koja se nije činila toliko značajnom budući da su ulasci iz Turske u Grčku morskim putem bili mnogostruko veći.

Tablica 4. Broj migranata u 2018. godini

\begin{tabular}{|c|c|c|c|c|c|c|c|c|c|c|c|c|c|c|}
\hline & 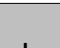 & 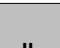 & & Vy & & & & 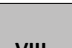 & (1) & y & 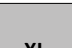 & $y$ & M & K \\
\hline & 1. & II. & IIII. & IV. & v. & VI. & VII. & VIII. & IX. & $x$ & II. & XII. & & \\
\hline \multirow{2}{*}{ Španjolska } & \multirow{2}{*}{2182} & \multirow{2}{*}{1518} & \multirow{2}{*}{1284} & \multirow{2}{*}{1706} & \multirow{2}{*}{3937} & \multirow{2}{*}{7323} & \multirow{2}{*}{8940} & \multirow{2}{*}{7022} & \multirow{2}{*}{8399} & \multirow{2}{*}{11788} & \multirow{2}{*}{5648} & \multirow{2}{*}{5578} & 58525 & 6800 \\
\hline & & & & & & & & & & & & & \multicolumn{2}{|c|}{65325} \\
\hline \multirow{2}{*}{ Italija } & \multirow{2}{*}{4182} & \multirow{2}{*}{1065} & \multirow{2}{*}{1049} & \multirow{2}{*}{3171} & \multirow{2}{*}{3963} & \multirow{2}{*}{3147} & \multirow{2}{*}{1969} & \multirow{2}{*}{1531} & \multirow{2}{*}{947} & \multirow{2}{*}{1007} & \multirow{2}{*}{980} & \multirow{2}{*}{359} & 23370 & 0 \\
\hline & & & & & & & & & & & & & \multicolumn{2}{|c|}{23370} \\
\hline \multirow{2}{*}{ Bugarska } & \multirow{2}{*}{99} & \multirow{2}{*}{55} & \multirow{2}{*}{132} & \multirow{2}{*}{129} & \multirow{2}{*}{102} & \multirow{2}{*}{72} & \multirow{2}{*}{263} & & & & & & 0 & 2533 \\
\hline & & & & & & & & 414 & $4 \pm 0$ & 245 & 320 & 05 & & \\
\hline & & & & & & & & & & & & & 32742 & 17472 \\
\hline GITAO & וזובע & 1010 & בנבוב & 7000 & 4002 & $3 / 45$ & 4210 & קבכד & $50 / 4$ & 0010 & 5120 & & & \\
\hline IPNO & 844 & 8 & 0 & 115 & 804 & 187 & 385 & 806 & 423 & 050 & 270 & 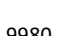 & 114637 & 26805 \\
\hline & & & & & & & & & & & & & & \\
\hline
\end{tabular}

Tablica 4 donosi statističke podatke o manjem nezakonitom ulasku migranata u EU preko južnih granica. Ukupan broj migranata koji su ušli u Europsku uniju preko njezinih južnih granica, ponovno je manji nego prethodne godine.

Ipak, broj novopridošlih migranata u Španjolskoj ponovno se udvostručio. Znakovita je i činjenica da nakon 2015. godine bilježimo prvi porast broja novopridošlih migranata u Grčkoj. Usto, triput se povećava broj migranata koji u Grčku ulaze iz Turske preko kopnene granice.

6 Više o SAR zonama vidi na http://www.imo.org/en/about/conventions/listofconventions/pages/international-convention-on-maritime-search-and-rescue-(sar).aspx

7 International Coordination Centre, vidi više u Međunarodnoj konvenciji o traganju i spašavanju na moru, točka 3.1.6 
S druge strane brojevi iz Italije značajno su manji 2018. godine nego 2017. godine. Opet je to pad od nekih osamdeset tisuća migranata. Gotovo peterostruko manji broj nego prethodne godine.

Općenito gledajući, na temelju ukupnih podataka možemo zaključiti da je EU nakon velike migrantske krize 2015./2016. u roku od dvije godine vratila kontrolu nad migrantskim kretanjima preko njezinih južnih granica. No, pogled na statističke podatke u gornjim tablicama jasno govori da EU još uvijek nema kontrolu nad tim kretanjima ni na zapadnosredozemnoj ni na istočnosredozemnoj ruti.

Kad usporedimo broj migranata pristiglih u Europsku uniju u razdoblju 2015. - 2018. godine možemo reći da Unija ima velike razloge proglasiti značajan napredak u "borbi" protiv nezakonita ulaska migranata na njezin teritorij. U odnosu na 2015. godinu broj migranata koji je tijekom 2018. ušao na područje Unije gotovo je deset puta manji. Ako statističke podatke iz gore prikazanih tablica prikažemo u obliku grafičkog prikaza, opći trend pada broja migranata, koji su nezakonito ušli u EU preko njezinih južnih granica, jasno je vidljiv.

Grafički prikaz 1. Ukupan broj migranata koji su ušli u EU 2015. - 2018.

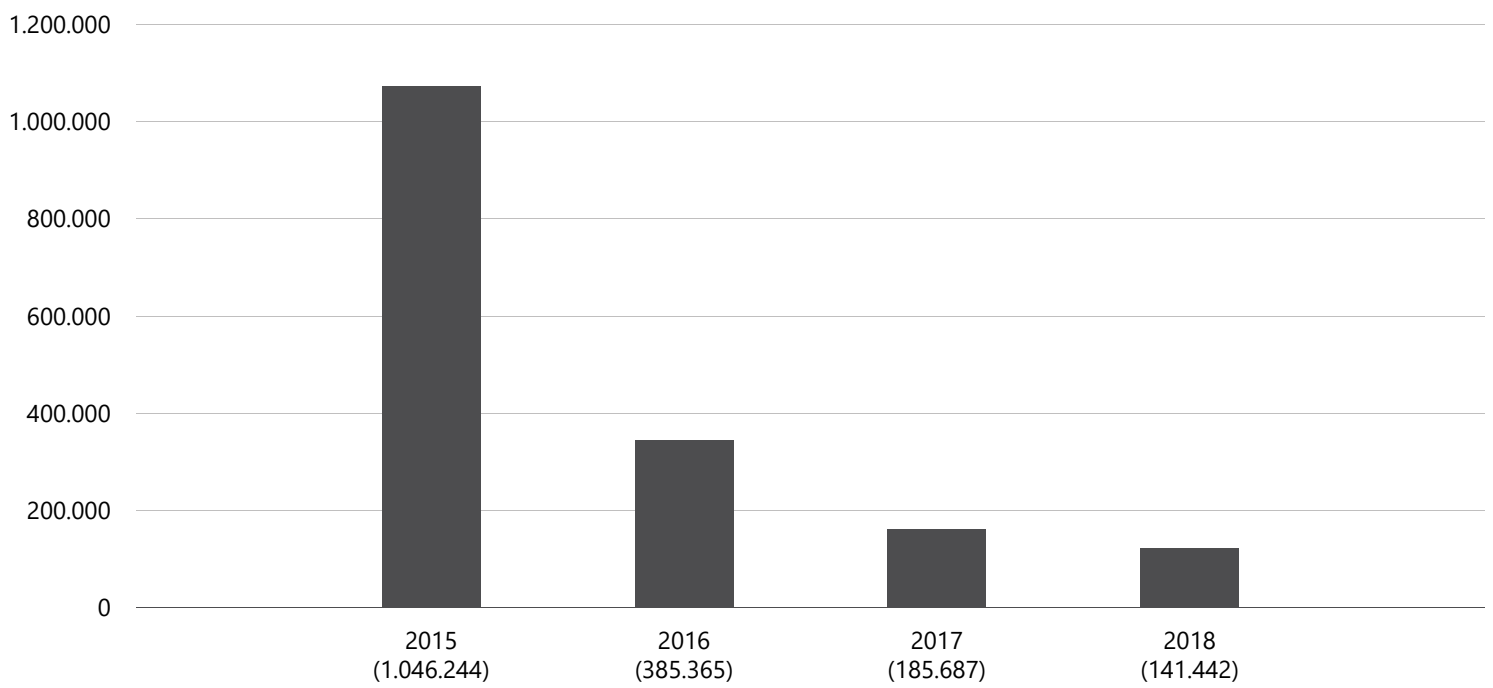

Evidentan je trend nagloga i velikog pada broja migranata pristiglih na teritorij Unije. Ovakvi statistički podatci jedan su od glavnih razloga i na prvi pogled opravdavaju stajalište potpredsjednika Europske komisije Fransa Timmermansa da se može smatrati da je "migrantska kriza okončana" (vidi uvod).

Ipak, ako ćemo biti mudri, osim gore spomenute izreke o brojevima, trebali bismo se prisjetiti i izreka o statistikama koje nas uvijek pozivaju na oprez. Svaka statistika, bez pravog analiziranja, može prikriti jednako onoliko koliko i otkriti.

Prva stvar koju ne smijemo zaboraviti jest da je razdoblje druge polovice 2015. i prvog tromjesečja 2016. godine, u pogledu migracija, bilo razdoblje koje je rezultiralo statističkom anomalijom bez presedana u povijesti Europske unije. Bilo je to razdoblje kada je ogromna masa migranata pristigla na područje EU-a s teritorija Turske, preko Grčke, i dalje tzv. zapadnobalkanskom rutom, prema središnjoj i sjevernoj Europi. Ti migranti koristili su vjekovni "most" između Azije i Europe, preko kojeg je u Europu pristiglo najviše azijskog utjecaja od početka ljudske rase. Počelo je to od širenja 
Antonio Vulas: Analiza statističkih podataka IOM-a vezanih za migracije na južnim...

homo sapiensa, zatim širenja poljoprivrede do nekih kasnijih sretnih i manje sretnih utjecaja, koji su spomenutim mostom najlakše dolazili do srca Europe i ostavljali najdublje tragove (Delanty, 2017).

No, kada govorimo o broju pristiglih migranata 2015., a i 2016. godine, te statističke podatke uvijek treba promatrati kao ekstrem koji se ne može nekritički stavljati u korelaciju sa statističkim podatcima za druga razdoblja.

Podatci navedeni u statistici IOM-a kažu da je tijekom 2015. godine iz Turske na područje Grčke, isključivo morskim putem, pristiglo ukupno 857363 migranta. Tako velik priljev nastavljen je i tijekom siječnja, veljače i ožujka 2016. godine.

Tablica 5. Broj migranata pristigao u Grčku iz Turske 2015. - svibnja 2016.

\begin{tabular}{|c|c|c|c|c|c|c|}
\cline { 2 - 6 } \multicolumn{1}{c|}{} & $\mathbf{2 0 1 5 .}$ & siječanj 2016 & veljača 2016. & $\begin{array}{c}\text { ožujak } \\
\mathbf{2 0 1 6}\end{array}$ & travanj 2016. & svibanj 2016. \\
\hline $\begin{array}{c}\text { Broj migranata } \\
\text { pristigao iz TR u GR }\end{array}$ & 857363 & 67415 & 57066 & 26971 & 3650 & 1721 \\
\hline
\end{tabular}

Grafički prikaz 2. Broj migranata pristiglih u Grčku iz Turske od siječnja 2016. - svibnja 2016.

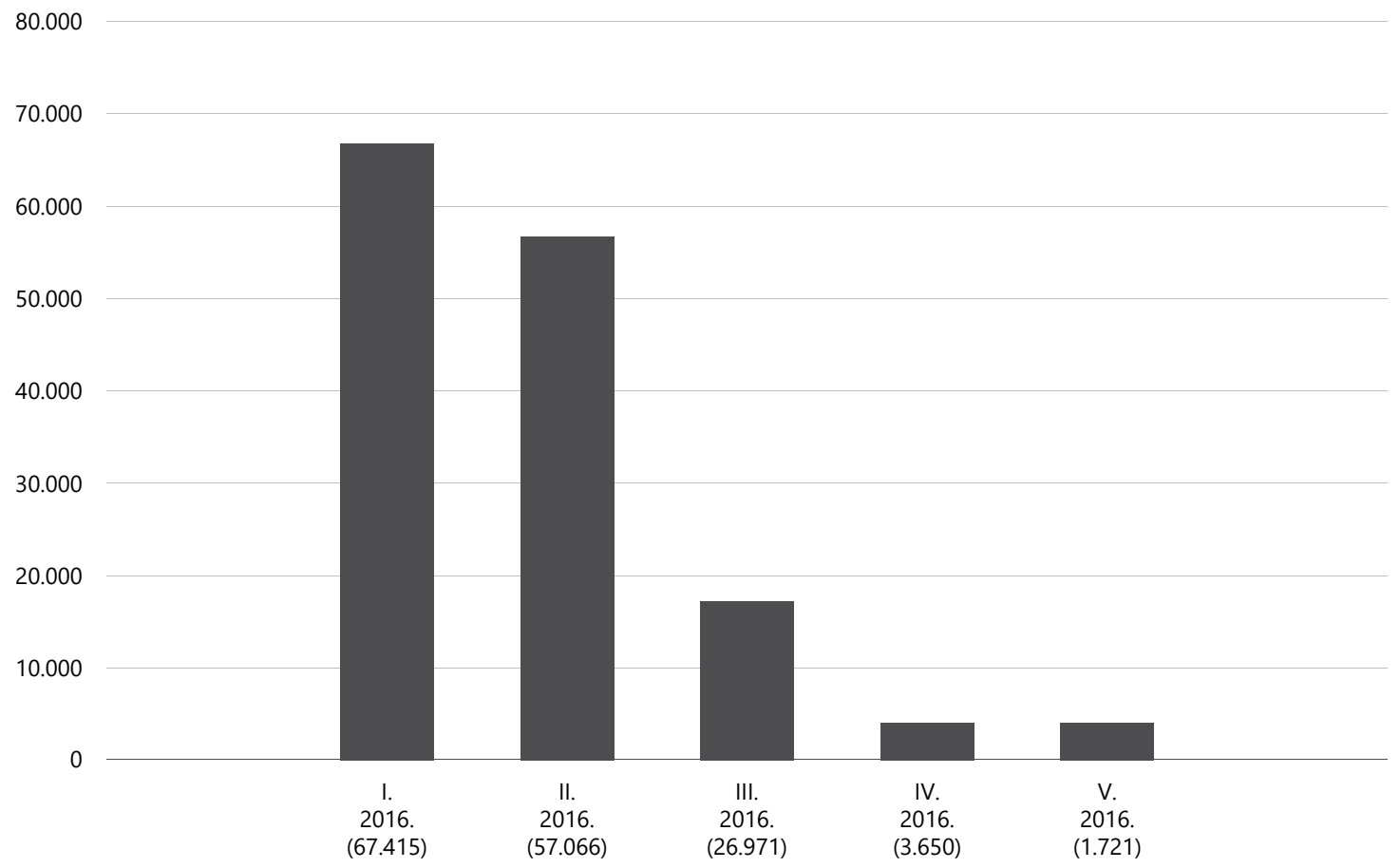

Unatoč tomu što i dalje postoje prijepori je li ovako nagli pad broja migranata koji su pristigli u Grčku iz Turske rezultat dogovora između EU-a i Turske ili mjera koje su poduzele zemlje okupljene u Salzburškom forumu, predvođene Austrijom, podatci pokazuju da tek u travnju, pa čak i u svibnju 2016. godine statistički podatci izlaze iz zone ekstrema u odnosu na statističke podatke prije započinjanja migrantskog vala 2015. godine.

Ipak, možemo reći da je ekstremno velik broj migranata pristiglih u Grčku iz Turske učinio i 2016. godinu godinom za koju statistički podatci o nezakonitom ulasku migranata značajno odudaraju od svih drugih takvih podataka prije započinjanja migrantskog vala godinu dana ranije. 
Pritom moramo primijetiti da se ni u 2015. ni u 2016. godini ne bilježe prelasci migranata iz Turske u Grčku preko tursko-grčke kopnene granice. Taj podatak važan je za kasniju analizu. Upravo taj smjer ulaska migranata u EU, njegov nagli porast i kasniji pad, učinio je ogromnu statističku promjenu u ovom razdoblju. Brojke priljeva migranata preko Italije i Španjolske, odnosno nepostojanje velikih statističkih nejednakosti u ovim dvjema državama, govore u prilog toj tvrdnji.

Tablica 6. Broj migranata pristiglih u Italiju 2015. - svibnja 2016.

\begin{tabular}{|c|c|c|c|c|c|c|c|}
\cline { 2 - 7 } \multicolumn{1}{c|}{} & $\mathbf{2 0 1 5 .}$ & $\mathbf{2 0 1 6 .}$ & $\begin{array}{c}\text { siječanj } \\
\mathbf{2 0 1 6 .}\end{array}$ & veljača 2016. & ožujak 2016. & travanj 2016. & svibanj 2016. \\
\hline $\begin{array}{c}\text { Broj migranata } \\
\text { pristigao u Italiju }\end{array}$ & 153842 & 181436 & 5273 & 3828 & 9676 & 9149 & 19925 \\
\hline
\end{tabular}

Tablica 7. Broj migranata pristiglih u Španjolsku 2015. - svibnja 2016.

\begin{tabular}{|c|c|c|c|c|c|c|c|}
\cline { 2 - 7 } \multicolumn{1}{c|}{} & $\mathbf{2 0 1 5 .}$ & $\mathbf{2 0 1 6 .}$ & $\begin{array}{c}\text { siječanj } \\
\mathbf{2 0 1 6 .}\end{array}$ & veljača 2016. & ožujak 2016. & travanj 2016. & svibanj 2016. \\
\hline $\begin{array}{c}\text { Broj migranata } \\
\text { pristigao u } \\
\text { Španjolsku }\end{array}$ & 3845 & 14558 & 492 & 222 & 351 & 451 & 575 \\
\hline
\end{tabular}

Kao što možemo vidjeti iz tablice 6, na području Italije na godišnjoj razini nije bilo tako drastičnih brojčanih razlika kao u Grčkoj (povećanje od 18 \%), no vidimo drastično povećanje broja dolazaka u svibnju 2016. u odnosu na prethodne mjesece iste godine. Uzrok tomu u svakom slučaju može biti poboljšanje vremenskih prilika na moru u svibnju, ali isto tako i "prigušivanje" istočnosredozemne rute.

Tablica 7 pokazuje nam veliko odstupanje broja pristiglih migranata u Španjolsku tijekom 2015. i 2016. godine (povećanje od $260 \%$ ), iako se u razdoblju od siječnja do svibnja 2016. godine ne primjećuju tako velika statistička odstupanja. Ukupan broj pristiglih migranata u Španjolsku tijekom 2016. godine, ako ga usporedimo s onim iz "krizne" 2015. godine, govori da se i na zapadnosredozemnoj ruti osjetilo "prigušivanje" istočnosredozemne rute, ali nešto kasnije. Kao što ćemo vidjeti kasnije u tekstu, ova "prelijevanja" migracijskog kretanja u uskoj su korelaciji.

Daljnju analizu statistike priljeva migranata na područje EU-a počet ću dvjema premisama:

- Razdoblje druge polovice 2015. i prvog tromjesečja 2016. godine bilo je razdoblje kretanja migranata istočnosredozemnom rutom u obujmu s kakvim se Europa nije suočila od Drugoga svjetskog rata. Stoga su statistički podatci za to razdoblje u usporedbi s bilo kojim drugim razdobljem prije ili poslije njega u velikom nerazmjeru. Ako to razdoblje usporedimo s bilo kojim drugim razdobljem, dolazimo do zaključka da je EU, nakon zaustavljanja masovnog priljeva migranata preko istočnosredozemne rute 2016. godine, ponovno vratila kontrolu na svojim vanjskim granicama u tom dijelu Unije. No, veliko smanjenje broja nezakonitih ulazaka migranata s ekstremno visokih brojeva na broj koji je još uvijek puno veći nego prije izbijanja "migracijske krize 2015./2016.", a osobito ako uzmemo u obzir povećan broj ulazaka u 2018. godini u odnosu na 2017. godinu, ne znači da je EU vratila potpunu kontrolu na svojim jugoistočnim granicama.

— Istočnosredozemna ruta bila je i ostat će ruta koja će najviše utjecati na kretanje statistike priljeva migranata u EU, unatoč tomu što je statistika srednjosredozemne rute napravila velik utjecaj na ukupnu statistiku 2018. godine i pojedine europske dužnosnike uljuljkala u uvjerenju da EU 
ponovno u potpunosti kontrolira migracijska kretanja na svojim vanjskim granicama. Razlozi, na kojima temeljim važnost istočnosredozemne rute, imaju svoj korijen u geografskim, povijesnim i geostrateškim činjenicama dokazanim tijekom stoljeća.

Dakle, ako uzmemo u obzir premisu da razdoblje druge polovice 2015. i prvog tromjesečja 2016. godine nije statistički "normalno" razdoblje, ostavit ćemo ga sa strane i usporedit ćemo kretanje migracija na istočnosredozemnoj ruti (Turska - Grčka) u razdoblju od travnja 2016. pa nadalje.

Ako uzmemo razdoblje 2016. godine, bez statistički "nenormalna" razdoblja od prva tri mjeseca i usporedimo ga s istim razdobljem 2017. godine dolazimo do podataka prikazanih u grafičkom prikazu 3.

\section{Grafički prikaz 3. Broj migranata pristiglih u Grčku od travnja do prosinca 2016. i 2017. godine}

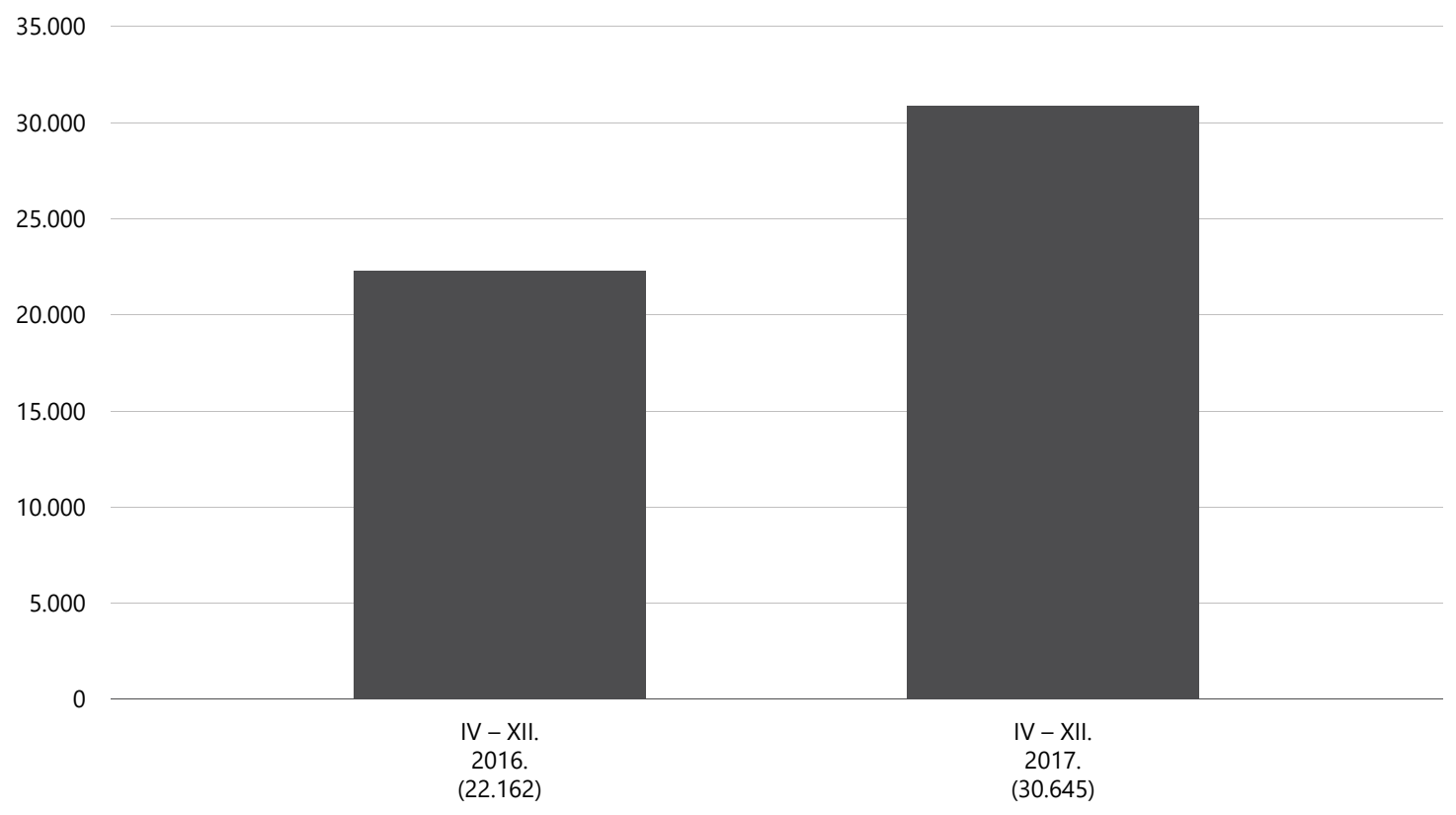

Nakon velikoga statističkog pada broja pristiglih migranata iz Turske u Grčku u travnju 2016. pa do kraja te godine u Grčku je pristiglo 22162 migranta. U istom razdoblju (travanj - prosinac 2017. godine) u Grčku je pristiglo 30645 migranata. Dakle, 28 \% više nego prethodne godine u istom razdoblju (travanj - prosinac).

Kada podatke sagledamo na takav način, vidimo da ne možemo biti zadovoljni trendom kretanja migracija na istočnosredozemnoj ruti nakon velikoga statističkog pada od ožujka do travnja 2016. godine. Usporedba ukupnog broja pristiglih migranata u ovim dvjema godinama daje nam razloge za tvrdnju da je EU na tom dijelu svojih vanjskih granica vratila kontrolu nad migracijskim kretanjima.

Da se ne bismo zaustavili na 2016. i 2017. godini u grafičkom prikazu 4 navode se statistički podatci od travnja 2016. do prosinca 2018. godine. Ni ovdje trend nije ohrabrujući. 


\section{Grafički prikaz 4. Broj migranata pristiglih u Grčku od travnja 2016. do prosinca 2018.}

8.000

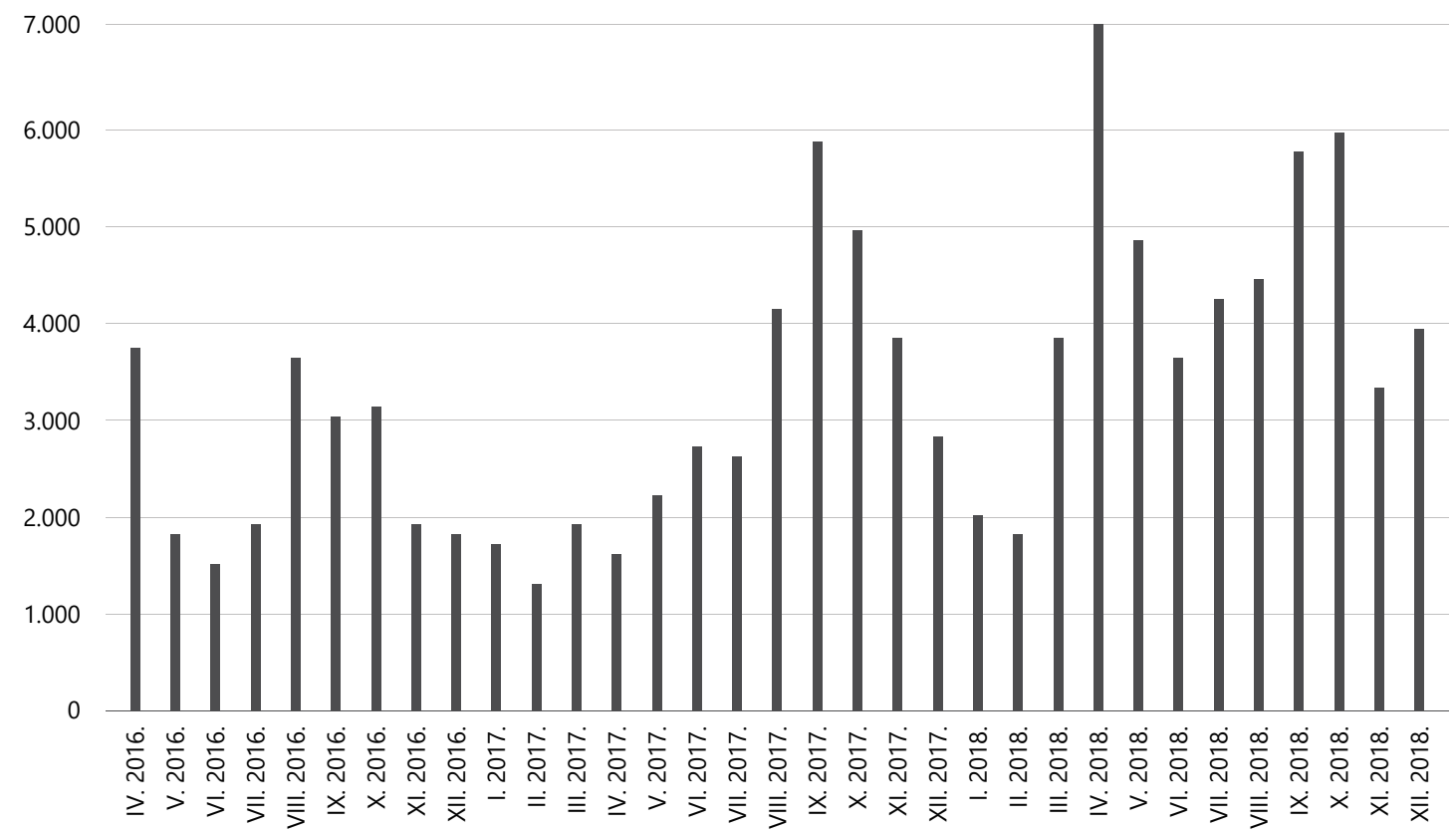

Što je, dakle, razlog optimizmu pri iznošenju statističkih podataka o broju pristiglih migranata nekih europskih dužnosnika? Najčešće spominjan razlog je taj što je broj pristiglih migranata u 2018. godini manji nego broj pristiglih migranata u 2017., a taj je broj opet manji nego onaj iz 2016. godine.

U navodima iz teksta možemo tražiti razloge zašto je broj pristiglih migranata u 2017. godini bio manji nego 2016. godine. Razlog tomu leži u činjenici što su prva tri mjeseca 2016. godine na istočnosredozemnoj ruti značajno utjecala na ukupnu godišnju statistiku te godine.

Ostaje pitanje, što se dogodilo 2018. godine. Ako je pad 2017. godine uzrokovan statistički "nenormalnim" mjesecima u 2016. godini, kakvo je objašnjenje za pad broja migranata u 2018. godini u odnosu na 2017. godinu? Razlog tomu je još jedna velika statistička anomalija na srednjosredozemnoj ruti. 
Antonio Vulas: Analiza statističkih podataka IOM-a vezanih za migracije na južnim...

Grafički prikaz 5. Broj migranata pristiglih u Italiju od 2015. do 2018.

200.000

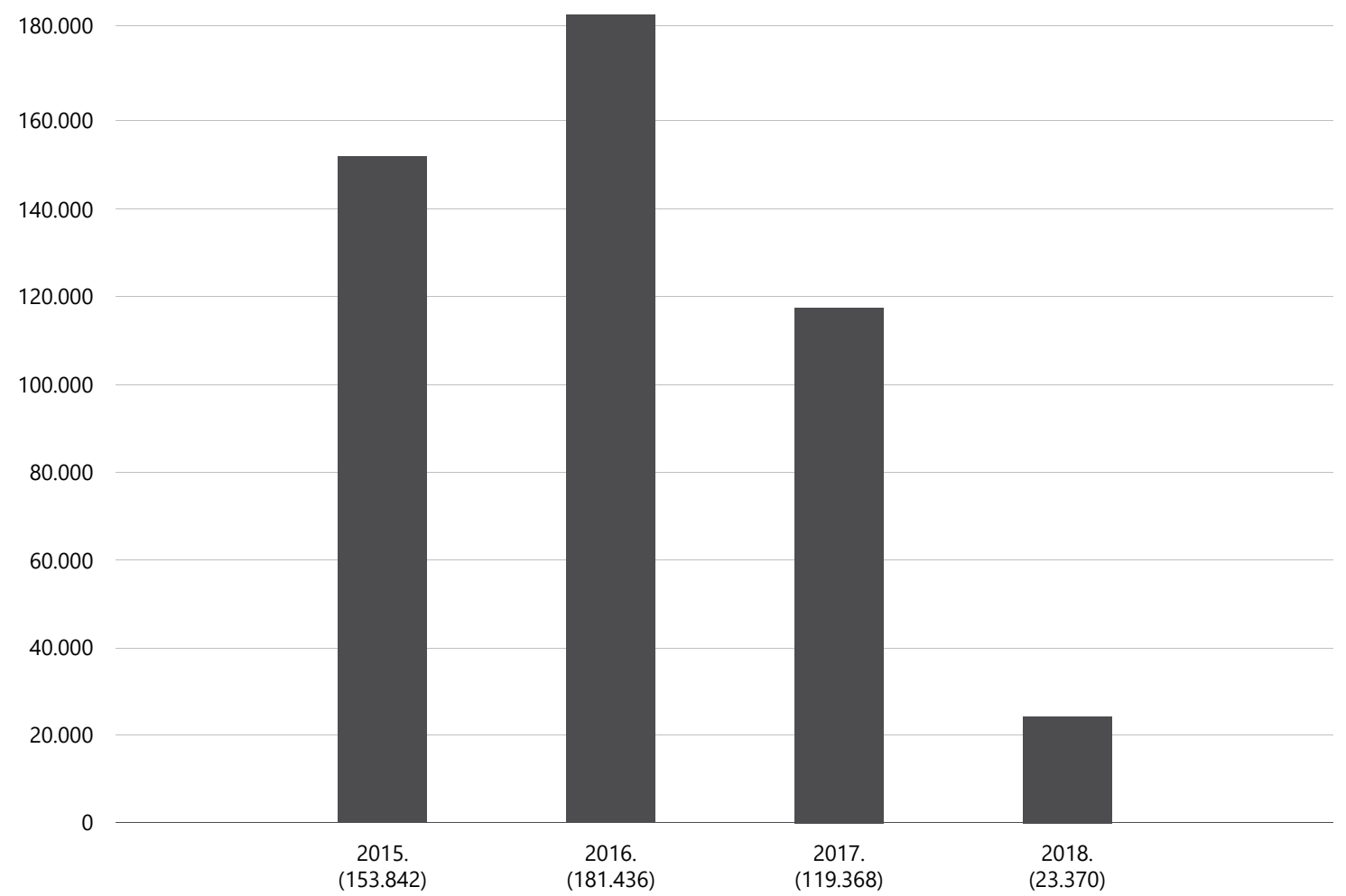

U grafičkom prikazu 5 vidljiv je broj pristiglih migranata u Italiju od 2015. do 2018. godine. Jasno se uočava statistička anomalija između 2017. i 2018. godine. Godine 2017. u Italiju je ušlo 119368 migranata, a u 2018. godini samo 23 370. Radi se o padu od 81 \%. Istovremeno je broj novopridošlih migranata u Španjolsku u istom razdoblju porastao s 28705 na 63325 migranata (vidi grafičke prikaze 6 i 7). Dakle, u Španjolskoj, za razliku od Italije, bilježimo porast od 55 \% (Parfitt, 2019). 
Grafički prikaz 6. Broj migranata pristiglih u Španjolsku od 2015. do 2018.

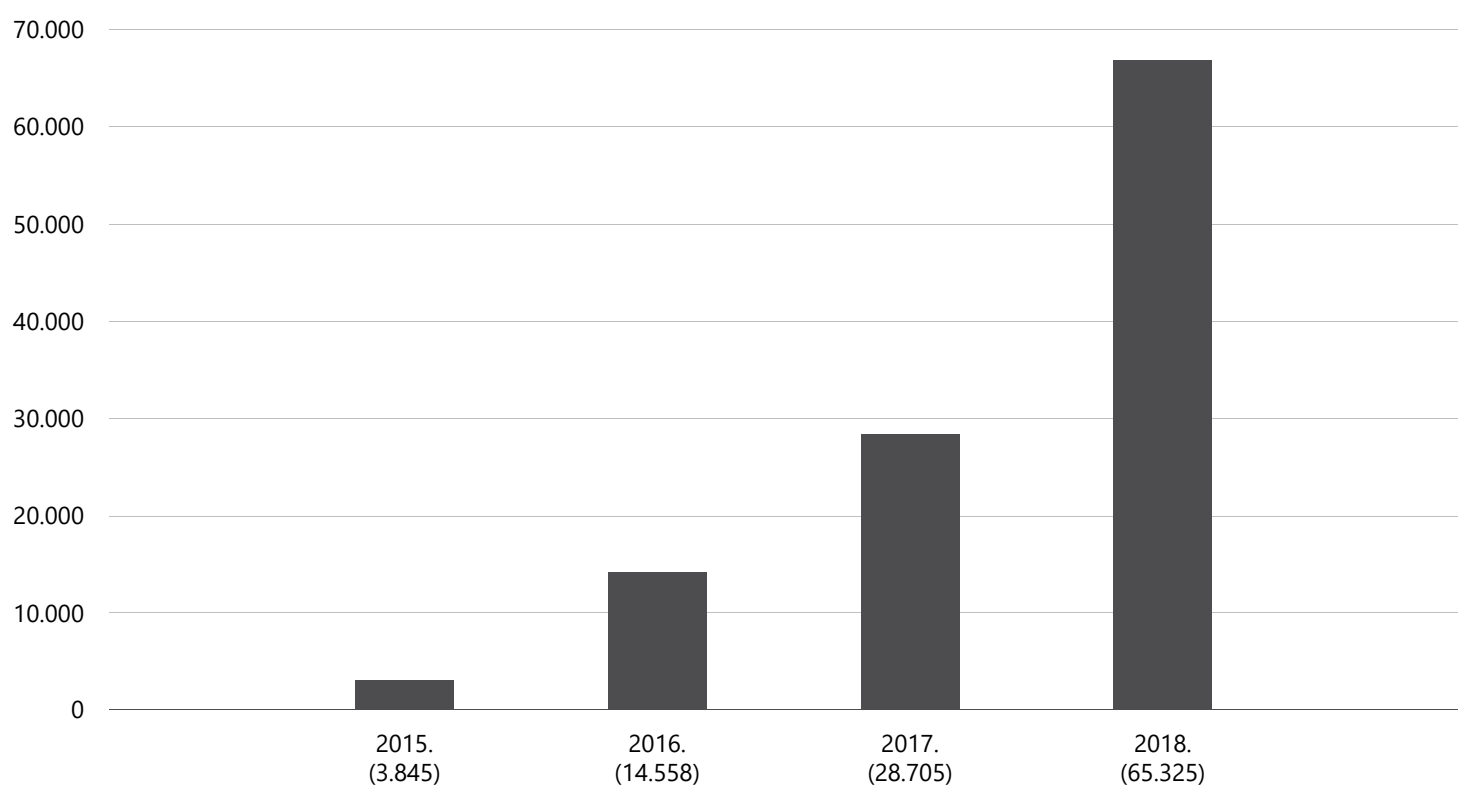

Grafički prikaz 7. Broj migranata pristiglih u Španjolsku od siječnja 2016. do studenoga 2018.

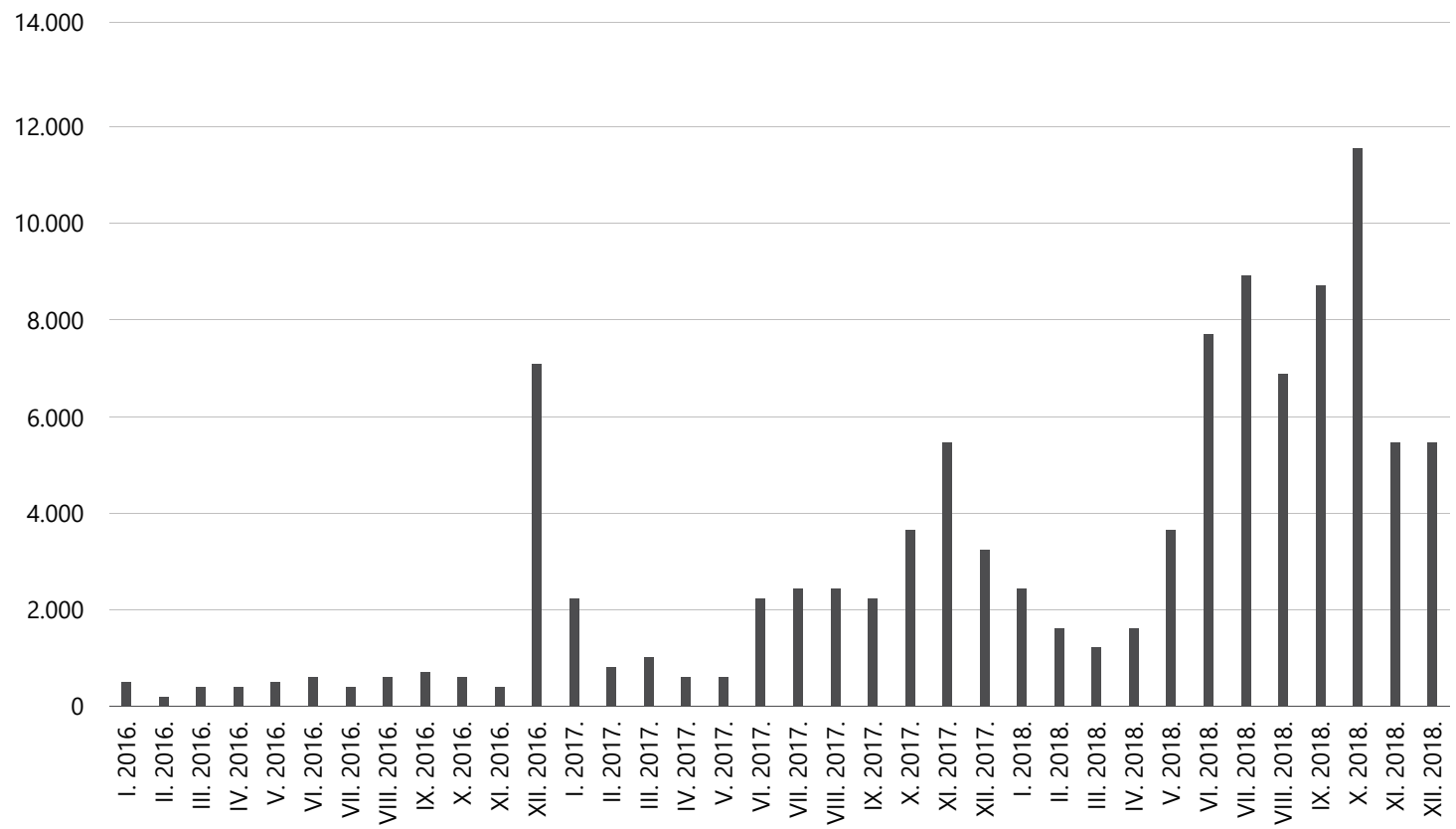

I ova statistička anomalija u podatcima za broj migranata pristiglih u Italiju uzrokovana je političkim odlukama, isto kao i ona u Grčkoj u 2016. godini. Naime, dolaskom nove strukture vlasti u Italiji promijenjen je odnos vlasti Italije prema plovilima nevladinih udruga, koje su na obale Italije dovozile najveći broj migranata koji su prema Europi kretali s libijskih obala (The Local, 2018). Zabranom pristajanja takvih plovila u talijanske luke došlo je do pada ukupna broja novopridošlih migranata u EU od osamdesetak tisuća osoba. To je dovelo do pada broja pristiglih migranata od nekih 40 $000 \mathrm{u}$ odnosu na 2017. godinu (Oppenheim, 2018). 
Da nije došlo do promjene u politici talijanske Vlade, a koja se počela osjećati već 2017 . godine, možemo pretpostaviti da broj migranata pristiglih u Italiju u 2018. godini ne bi bio toliko manji u odnosu na 2017. godinu i tada ne bismo imali razloga za optimizam.

Razloge za optimizam umanjuje stanje u Grčkoj i u Španjolskoj. Na tim granicama evidentan je trend stalna rasta broja migranata. Grafički prikazi 4, 6 i 7 jasno pokazuju taj uzlazni trend.

Zanimljiv je i trend porasta broja migranata na kopnenoj grčko-turskoj granici. Dok je u "kriznoj" 2015. i 2016. godini ulazak migranata u Grčku iz Turske preko kopnene granice bio toliko neznatan da ga statistike uopće ne bilježe, u 2017. godini taj je broj značajno porastao da bi u 2018. godini broj bio toliki da su grčke vlasti odlučile otvoriti nove "hotspotove" na sjeveru Grčke da bi bile sposobne nositi se s novim priljevom migranata (Kokkinidis, 2019).

\section{Grafički prikaz 8. Broj migranata pristiglih u Grčku iz Turske preko kopnene granice}

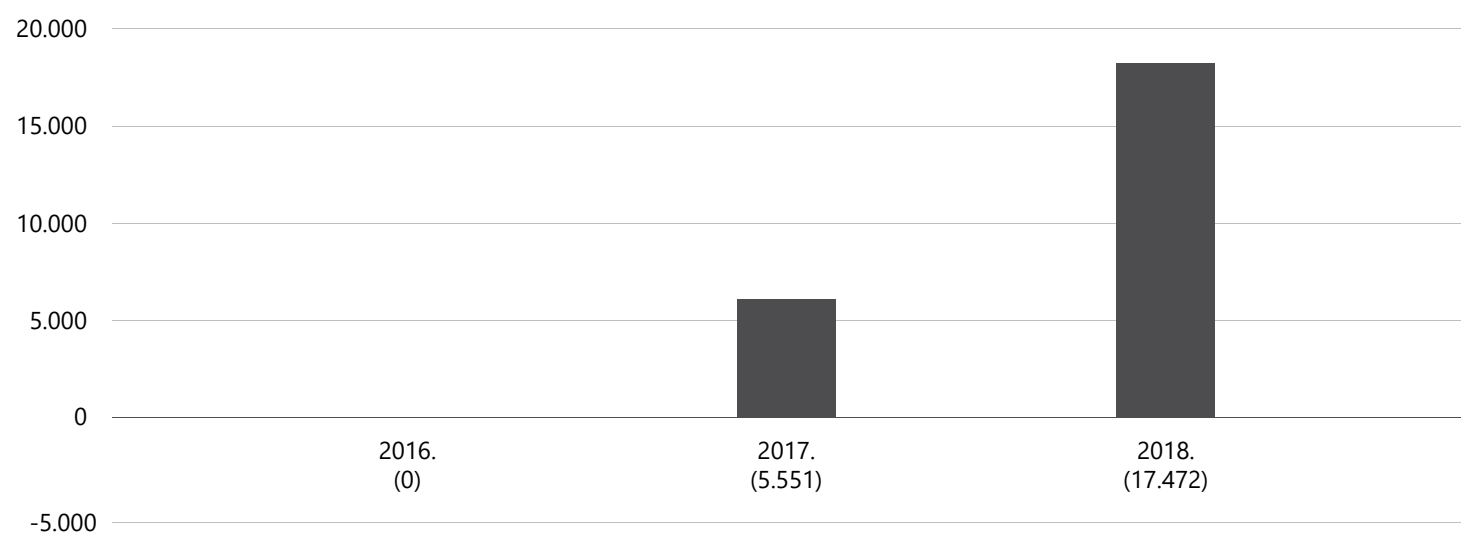

Za to vrijeme na bugarsko-turskoj kopnenoj granici postoji trend opadanja broja migranata koji su iz Turske ušli u Bugarsku ako usporedimo razdoblje od 2015. do 2018. godine. No, ako primijenimo istu logiku i pokušamo staviti statistički "nenormalnu" 2015./2016. godinu izvan razmatranja, vidimo da je broj ulazaka na tom dijelu vanjske granice EU-a približno jednak. 


\section{Grafički prikaz 9. Broj migranata pristigao u Bugarsku iz Turske preko kopnene granice}

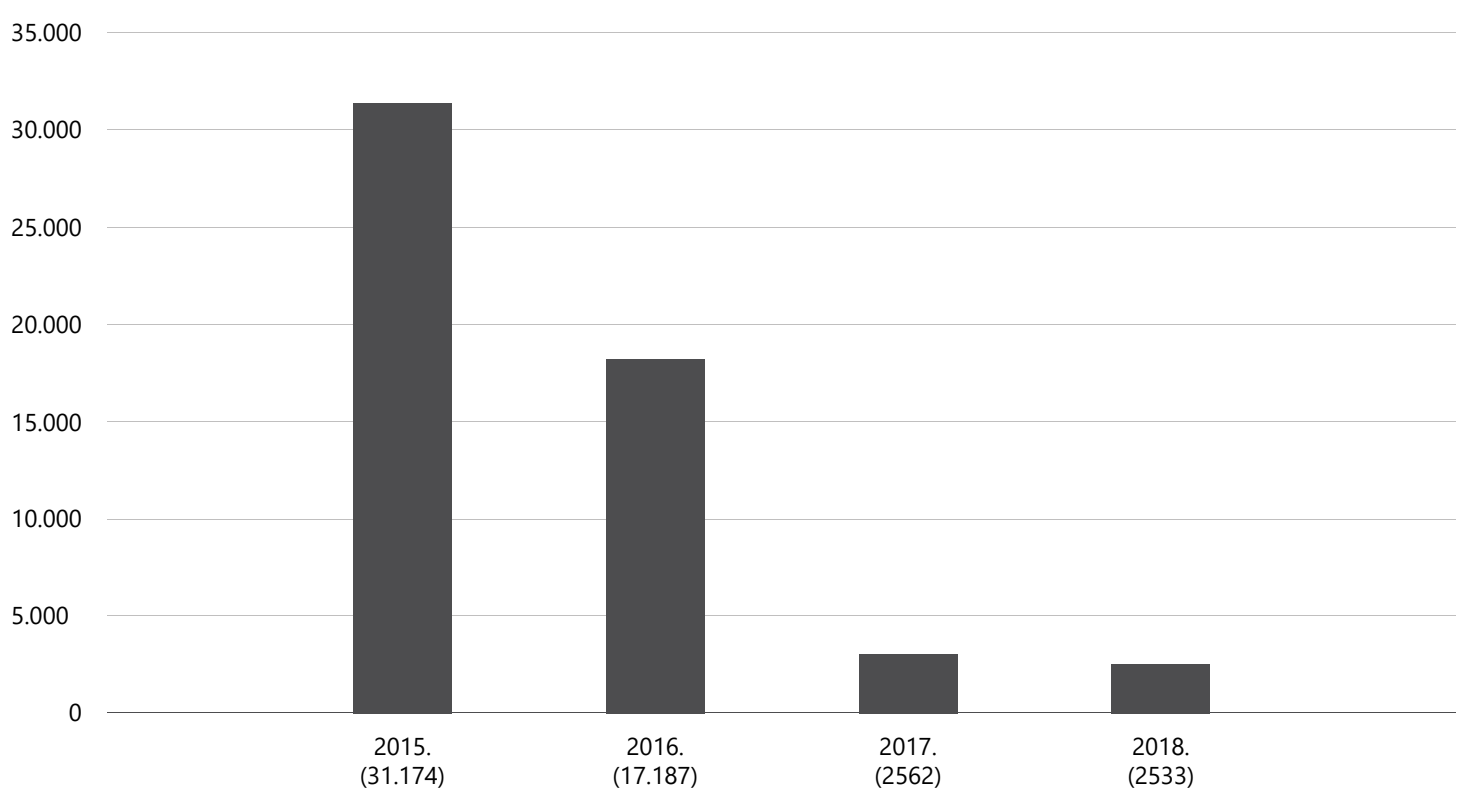

Ipak, kada govorimo o kretanjima migracija koje su iz Turske tijekom 2016. godine ušle u Bugarsku preko kopnene granice, zanimljiv je podatak da je naglim padom broja migranata u travnju 2016. godine, koji su morskim putem stizali iz Turske u Grčku, došlo do velikog porasta broja migranata koji su ulazili u Bugarsku kopnom.

Tablica 8. Broj migranata pristiglih u Bugarsku iz Turske u 2016. godini preko kopnene granice

\begin{tabular}{|c|c|c|c|c|c|c|c|c|c|c|c|}
\hline $\begin{array}{c}\text { I. } \\
\text { 2016. }\end{array}$ & $\begin{array}{c}\text { II. } \\
\mathbf{2 0 1 6 .}\end{array}$ & $\begin{array}{c}\text { III. } \\
\mathbf{2 0 1 6 .}\end{array}$ & $\begin{array}{c}\text { IV. } \\
\mathbf{2 0 1 6 .}\end{array}$ & $\begin{array}{c}\text { V. } \\
\mathbf{2 0 1 6 .}\end{array}$ & $\begin{array}{c}\text { VI. } \\
\mathbf{2 0 1 6 .}\end{array}$ & $\begin{array}{c}\text { VII. } \\
\mathbf{2 0 1 6 .}\end{array}$ & $\begin{array}{c}\text { VIII. } \\
\mathbf{2 0 1 6 .}\end{array}$ & $\begin{array}{c}\text { IX. } \\
\mathbf{2 0 1 6 .}\end{array}$ & $\begin{array}{c}\text { X. } \\
\mathbf{2 0 1 6 .}\end{array}$ & $\begin{array}{c}\text { XI. } \\
\mathbf{2 0 1 6 .}\end{array}$ & $\begin{array}{c}\text { XII. } \\
\mathbf{2 0 1 6 .}\end{array}$ \\
\hline 596 & 450 & 524 & 1328 & 1201 & 1436 & 1236 & 4022 & 2645 & 2133 & 1129 & 487 \\
\hline
\end{tabular}

Kao što vidimo na još jednom primjeru, pokazalo se da se broj migranata povećava na jednoj ruti kada se taj priljev "priguši” na jednoj od uobičajenih ruta priljeva migranata u Europsku uniju. Čimbenici koji utječu na smanjenje broja migranata na jednoj ruti, brzo dovedu do povećanja broja migranata na ruti koja je u izravnoj korelaciji s onom prvom.

Kada govorimo o južnim granicama Europske unije i migracijama preko tih granica, ova međuovisnost broja migranata više puta je dokazana.

\section{Zaključak}

Uzimajući u obzir da se ovaj rad bavio uglavnom statističkim podatcima, najlogičnije bi bilo završiti ga zaključkom koji bi bio u numeričkom duhu. Međutim, time bi se potpuno poništilo značenje gore iznesenih podataka.

Kao što smo već rekli, brojke ne mogu lagati. Osobito ako se služimo brojkama i statističkim podatcima koje nismo osobno prikupili. Bez obzira što ovaj rad nema svrhu ulaziti u opravdanje ili kritiku političkih poteza pojedinih država članica, koje su utjecale na statističke podatke, neupitno je 
da je politika pojedinih država članica, pri čemu ponajprije mislim na politiku nove talijanske Vlade na središnjem Sredozemlju, utjecala na migrantska kretanja, a samim tim i na statističke podatke.

U svjetlu nadolazećih izbora za Europski parlament, kada će ova tema biti jedan od "zaglavnih kamena" svih političkih grupacija u borbi za glasove, interpretacija podataka ne smije biti oslobođena kritičkog promišljanja.

Gore iznesene podatke lako je interpretirati optimistično. No, koliko bi to bilo mudro u situaciji kada možemo reći da nijedan od uzroka pokretanja i održavanja ovakvog vala migranata prema južnim granicama Unije nije istražen u onoj mjeri koja bi Uniji omogućila poduzimanje učinkovitih mjera na ovom planu. No, ako kod ovakve tvrdnje o nepostojanju kvalitetne analize o uzrocima i griješimo, sasvim je sigurno da zasada takve analize ne daju učinkovite rezultate. Sudeći prema trenutnom stanju, bit će potrebno još mnogo vremena dok se migracijska kretanja, barem na istočnosredozemnoj ruti, vrate u stanje kakvo je bilo prije 2015. godine (Turkish Minute, 2019). Nesumnjivo je da je problem pritiska priljeva migranata u EU i dalje prisutan iako nas ukupni statistički podatci mogu lako zavarati.

Isto tako, nesumnjivo je da su na ovakvo stanje utjecale političke odluke. Bilo da se radi o političkim odlukama na razini Unije, na razini nekoliko država ili na nacionalnoj razini, politika EU-a i njezinih država članica može utjecati na migracijska kretanja preko njezinih vanjskih granica.

U prvom slučaju, kod nagloga pada broja migranata pristiglih u Grčku iz Turske u travnju/svibnju 2016., još uvijek postoje kontradiktorna razmišljanja što je uzrok tom padu. Sporazum zemalja okupljenih u Salzburški forum, predvođenih Austrijom, da učine sve kako bi se na njihovim granicama zaustavio neometan prelazak migranata iz Grčke prema središnjoj Europi ili pak sporazum između EU-a i Turske, kojim se Turska obvezala učiniti sve da spriječi neometan izlazak migranata prema Europi.

U drugom slučaju ne postoji dilema. Odluke nove talijanske Vlade, i njezina ministra unutarnjih poslova g. Salvinija, da brodovima nevladinih organizacija onemogući iskrcavanje migranata koje su isti „spasili" na otvorenom moru, dovela je do drastična pada broja migranata pristiglih u Italiju.

Dakle, nesumnjivo se radi o utjecaju politike na kretanje migracija. I unatoč tomu što vrlo često možemo čuti da nikakva politika ne može zaustaviti migracije, također je nesumnjivo da politika može uvelike utjecati na migracijska kretanja.

Jednako kao i statistički podatci i politike se mogu različito interpretirati. Za jedne će ista politika biti hvalevrijedna, a za druge će biti populistička i nehumana. Ne ulazeći u ocjenu opravdanosti i poželjnosti pojedinih političkih čimbenika, koji su utjecali na statistiku migracija, problem je u tome što će i jedni i drugi vrlo često interpretirati statističke podatke onako kako njima odgovara u tom trenutku. Analiza će se provoditi onako da će se naglašavati one činjenice koje njihovoj interpretaciji idu u prilog dok će se one suprotne prešućivati.

U svakom slučaju, smanjenje broja novopridošlih migranata u Europsku uniju u razdoblju nakon 2015. teško da se može pripisati nekoj uspješnoj politici na razini Unije na ovom polju. Na takvu politiku morat ćemo još pričekati dok prikupljamo statističke podatke. 


\section{Literatura}

Akrap, G., Kalinić, P. (2015). Forced migrations - powerful non-kinetic weapon. National security and the future, 16(2-3), 10-28.

Delanty, G. (2017). Europe and Asia Beyond East and West. London and New York: Routledge .

Dennison, A., Geddes, A. (2018). Brexit and the perils of 'Europeanised' migration. Journal of European Public Policy Issue, 25(8), 1137-1153. doi: 10.1080/13501763.2018.1467953

FRONTEX (2019). Risk analysis for 2019. Preuzeto s: https://frontex.europa.eu/publications/riskanalysis-for-2019-RPPmXE (15.02.2019.)

FRONTEX (2015). Annual risk analysis 2015. Preuzeto s: $h$ ttps://frontex.europa.eu/assets/Publications/ Risk_Analysis/Annual_Risk_Analysis_2015.pdf (15.02.2019.)

IOM (2016). Mixed migration flows in the Mediterranean and beyond - Flow monitoring compilation, 2015 annual report. Preuzeto s: https://www.iom.int/sites/default/files/situation_reports/file/Mixed-Flows-Mediterranean-and-Beyond-Compilation-Overview-2015.pdf (19.02.2019.)

Kokkinidis, T. (2019). Greece records threefold rise in migrant arrivals over land. Preuzeto s https:// greece.greekreporter.com/2019/01/12/greece-records-threefold-rise-in-migrant-arrivals-over-land/ (23.02.2019.)

Mikac, R. i Dragović, F. (2017). Masovne migracije: izazovi, posljedice i put naprijed. Forum za sigurnosne studije, 1(1), 130-152.

Oppenheim, M. (2018). Italy's far - right government asks EU to block refugee ships from its ports. Preuzeto s: https://www.independent.co.uk/news/world/europe/italy-government-eublock-refugee-ships-matteo-salvini-ports-a8437516.html (23.02.2019.)

Parfitt, J. (2019). Migrants arriving in Spain by boat quadruple in number as route becomes most popular into Europe. Preuzeto s: https://www.theolivepress.es/spain-news/2019/02/06/ migrants-arriving-in-spain-by-boat-quadruple-in-number-as-route-becomes-most-popular-into-europe/ (23.02.2019.)

The Local (2018). Italy will close ports to NGO migrant ships "all summer" despite drownings. Preuzeto s: https://www.thelocal.it/20180629/italy-will-close-ports-to-ngo-migrant-ships-allsummer-despite-drownings (23.02.2019.)

Turkish Minute (2019). Rumoro of dispach to Europe sparks false hope among Syrian refugees in Turkey. Preuzeto s: https://www.turkishminute.com/2019/02/14/rumor-of-dispatch-toeurope-sparks-false-hope-among-syrian-refugees-in-turkey/ (23.02.2019.)

Vurnek, D., Bengaz, A. i Perkov, M. (2018). Sigurnosni aspekti migracija. Acta Economica et turistica, 4(2), 157-180. doi: 10.1515/aet-2018-0011 
Antonio Vulas

Police Advisor Head of the Department for Illegal Migration of the Police Administration of Split-Dalmatia

\title{
IOM's statistic data analysis related to migrations on the EU southern borders 2015-2018
}

\begin{abstract}
Summary
Article concerns the problems of interpretation of the statistical data about the migration flow on the southern borders of the European union in the period 2015-2018. Using the statistical data produced by a specialized agency of the UN it aims to emphasis the problem of the arrivals of the migrants after the "great migration crisis 2015-16" and on the problems of the interpretation of those statistical data. Underlying the importance of the statistical overviews of the previous periods for determining the future activities it also underlies the importance of analysis of the statistical changes and the factors which influenced them. Emphasize has been put on a need for a realistic overview of the factors which influenced the statistic changes and determination of the nature of that influence. Furthermore, the article shows that every analysis of the statistic changes the emphasise should be put on defining of the factors which have influenced the statistic changes, determination of the nature of those factors, on their durability and the possibility of repeating of those factors.
\end{abstract}

Keywords: migrations, EU southern borders, statistical data, International organization for migrations

8 Opinions and views expressed in this paper do not necessarily represent the official position of the Ministry of Interior of the Republic of Croatia 